\title{
Study on the Synthesis of 6-Hydroxyhexyl 5-(Hydroxymethyl) Furan-2- Carboxylate from 5-Hydroxymethylfurfural (HMF) and Alkanediols
}

Nghiên cứu tổng hợp 6-hydroxyhexyl 5-(hydroxymethyl) furan-2-carboxylate từ 5hydroxymethylfurfural (HMF) và rượu no hai chức mạch hở

\author{
Vu Trung Nam, Nguyen Duy Hieu, Nguyen Tuong Huy, Tran Thi Thuy, \\ Tran Thuong Quang, Tran Quang Tung* \\ School of Chemical Engineering, Hanoi University of Science and Technology, Hanoi, Vietnam \\ *Email: tung.tranquang@hust.edu.vn
}

\begin{abstract}
Nowadays, due to the fact that the term 'sustainable development' has caught everyone's attention, chemists have been researching substances which obtainable via synthesizing biocompounds. Recently, scientists found out that 5-hydroxylmethylfurfural (HMF), which can be synthesized via dehydration reaction of common biocompounds like polysaccharides, has a great potential of forming novel derivatives to utilize in the biopolymer manufacturing field. HMF oxidative esterification is one of the notable reactions of which the outcome seems promising and applicable. In this research, the esterification of HMF and hexane-1,6-diol took place directly in DMSO or TEA solvent using $\mathrm{Ru} / \mathrm{C}, \mathrm{Co}_{3} \mathrm{O}_{4}-\mathrm{N} @ \mathrm{C}$ as catalysts, base $\mathrm{K}_{3} \mathrm{PO}_{4}$; with oxygen 1 bar as an oxidant. LC-MS/MS analysis was used to detect the presence of the ester products; however, due to the low conversion and selectivity, the content of desired product is not enough to isolate and confirm its structure.
\end{abstract}

Keywords: HMF, oxidative esterification, biopolymer.

Tóm tắt

Trong xu hướng phát triển kinh tế và khoa học công nghệ bền vững, các nhà hóa học nghiên cứu các chất được tổng hợp từ các hợp chất sinh học. Ngày nay, 5-hydroxylmethylfurfural (HMF) thu được từ phản ứng tách nước của một số polisaccarit quen thuộc, thu hút được sự quan tâm đặc biệt do tiềm năng ứng dụng từ các dẫn xuất của phân tử này. Phản ứng este oxi hóa HMF là một trong những chuyển hóa tiêu biểu mà sản phẩm thu được có ý nghĩa quan trọng trong lĩnh vực biopolymer. Trong nghiên cứu này, monoeste giữa HMF và hexane-1,6-diol được tạo thành từ phản ứng trực tiếp của 2 chất này với tác nhân oxi hóa là oxi (1 bar) khi sử dụng hệ xúc tác $\mathrm{Ru} / \mathrm{C}$ và $\mathrm{Co}_{3} \mathrm{O}_{4}-\mathrm{N} @ \mathrm{C}$ trong dung môi DMSO hoặc $T E A$, bazơ vô co $\mathrm{K}_{3} P \mathrm{PO}_{4}$. Phân tích $L C$ MS/MS phát hiện sự có mặt của este sản phẩm. Tuy nhiên, hiệu suất và độ chọn lọc của phản ứng thấp, hàm lượng sản phẩm mong muốn chưa đủ lớn để phân lập và xác nhận cấu trúc.

Từ khóa: HMF, oxidative esterification, biopolymer.

\section{Introduction}

The interest in polymers synthesized from renewable resources has been rising due to issues related to the environment, as well as for the thermal and energy transportation, is still based on the fossilfuel reservoir $[1,2]$. Consequently, a variety of natural macromolecules and renewable monomers, such as polysaccharides, lignin, succinic acid, vegetable oils, terpenes, and furan-based derivatives, have emerged in the preparation of various polymers $[3,4]$. One promising biomass-derived platform chemical is 5-hydroxymethylfurfural (HMF), which is suitable for alternative polymers. The ability to synthesize HMF directly from raw natural cellulose would remove a major barrier to the development of sustainable HMF platform $[5,6]$. Due to the importance of $\mathrm{HMF}$, research works have focused on several key aspects: (1) biological properties, such as the metabolism of HMF and toxicological effects; (2) synthesis of HMF including the catalysts used, the feedstocks used, and the solvent systems, (3) derivatives of HMF as biofuels precursors, fine chemicals, monomers for polymers; and (4) industrial production of HMF and its derivatives.

One of the most important applications of HMF is to synthesize monomers for polymers, such as 2,5-furandicarboxylic acid (FDCA) and 2,5-bis(hydroxymethyl) furan (BHF). In addition to the synthesis of FDCA-based polyesters, their physical properties (i.e., crystallinity, thermal and mechanical properties, thermal degradation, structural properties and permeability) have been investigated as well. The

ISSN: 2734-9381

https://doi.org/10.51316/jst.153.etsd.2021.31.4.9

Received: May 20, 2020; accepted: September 14, 2020 
thermal and barrier properties of polyethylene 2,5-furandicarboxylate (PEF) were highly comparable to their analogue polyethylene terephthalate (PET) [7-11].

The direct conversion of alkanediol an alcohol and HMF into their mono- and diesters has strong implications in polymerization reactions since the resulting products can be employed as monomer units for the polycondensation crosslinking. Industrially, the esterification of diols with fatty acids to their monoand diesters involves the presence of alkaline catalysts at high temperatures $\left(170-210^{\circ} \mathrm{C}\right)$. On the other work, the selective oxidation of alcohols to esters using heterogeneous $\mathrm{Co}_{3} \mathrm{O}_{4}-\mathrm{N} @ \mathrm{C}$ catalysts under mild conditions had been investigated for benzylic, heterocyclic, aliphatic alcohols. The application of $\mathrm{Co}_{3} \mathrm{O}_{4}-\mathrm{N} @ \mathrm{C}$ catalysts in the presence of oxygen, the cross and self-esterification of alcohols to esters proceeds in good to excellent yields $[12,13]$.

The catalytic activity of $\mathrm{Co}_{3} \mathrm{O}_{4}-\mathrm{N} @ \mathrm{C}$ catalysis for HMF oxidative esterification was also studied and showed positive results $[14,15]$. The nearest trials of HMF were limited to the coupling reaction with methanol. Along with methyl ester, alkanediol and HMF-derived diesters are potential alternatives to FDCA in the conventional FDCA-based polymers manufacturing [16,17]. In addition, single esterification products can be used as novel diol monomers for the crosslinking reaction. Whenever an alkanediol takes part in an esterification reaction, the presence of second hydroxyl group in the reactant can reduce the esterification capability of the first hydroxyl group. This effect depends on the length of the alkyl chain between the two hydroxyl groups. Besides, the spatial effect of long chain alcohols also affects the conversion of esterification.

In our research, the esterification between 5-hydroxymethylfurfural and diols using Ruthenium, $5 \%$ on activated carbon powder reduced and $\mathrm{Co}_{3} \mathrm{O}_{4}$ $\mathrm{N} @ \mathrm{C}$ catalysts under mild conditions has been investigated.

\section{Experiment}

\subsection{Chemicals}

The Ruthenium, $5 \%$ on activated carbon powder reduced 11748 LOT: U06A011, CAS: $7440-18-8$ was purchased from Alfa Aesar. $\mathrm{Co}_{3} \mathrm{O}_{4}-\mathrm{N} @ \mathrm{C}$ catalyst was supported by Leibniz-Institute for Catalysis $[12,13]$. 5-Hydroxymethylfurfural (95\%) was purchased from Fluorochem Ltd and stored under refrigeration. Hexane-1,6-diol was purchased from Fischer Scientific. Molecular sieves were activated before using. They were added to a dry flask and heat to $120^{\circ} \mathrm{C}$ with an oil bath under high vacuum overnight using a flow control adapter (t-joint). Refill with argon and use as needed. Butan-1,4-diol was purchased from Sigma - Aldrich. $\mathrm{K}_{3} \mathrm{PO}_{4}, \mathrm{~K}_{2} \mathrm{CO}_{3}$, TEA, DMSO, n-heptan were purchased from Merck.

\subsection{Esterification of HMF and Diols}

The 50 milligrams of $\mathrm{Ru} @ \mathrm{C}$ catalyst (5.0 mol\%) and $\mathrm{K}_{2} \mathrm{CO}_{3}(0.1 \mathrm{mmol})$ were added to an oven-dried Schlenk tube. Then, Dimethyl sulfoxide $(4 \mathrm{~mL})$ and HMF (0.5 mmol) were added sequentially. The Schlenk tube was evacuated, refilled with $1 \mathrm{bar} \mathrm{O}_{2}$, and closed with septum. The reaction was stirred at $12{ }^{\circ} \mathrm{C}$ (refluxed condenser was fixed) for $24 \mathrm{~h}$. After that, $3 \mathrm{mmol}$ of hexane-1,6-diol and 25 milligrams of $\mathrm{Co}_{3} \mathrm{O}_{4}-\mathrm{N} @ \mathrm{C}(\mathrm{Co}-\mathrm{L} 1 / \mathrm{C})$ catalyst $(2.5 \mathrm{~mol} \% \mathrm{Co})$ were added sequentially. The reaction was stirred at $120^{\circ} \mathrm{C}$ for another $24 \mathrm{~h}$ by passing 1 bar $\mathrm{O}_{2}$. After cooling the reaction mixture to room temperature, the catalyst was filtered off, and the sample of the mixture was directly subjected to LC-MS/MS (ESI) analysis.

Characterization of the final product was carried out using an Agilent 6210 Time-of-Flight LC/MS instrument. For mass spectroscopy using ESI ionization source, positive ion mode, and the spray voltage was settled up at $4000 \mathrm{~V}$.

\section{Results and Discussion}

\subsection{Solvent Screening}

Table 1 showed the effect of different solvents to the reaction between HMF and hexane-1,6-diol. Fig. 1 shows possible pathways and products for the oxidative esterification of HMF with hexane-1,6-diol.

The ESI-TOF mass spectrum of the product obtained using $\mathrm{K}_{3} \mathrm{PO}_{4}$ base and DMSO solvent at $120^{\circ} \mathrm{C}$ for $48 \mathrm{~h}$ (Entry 1 ). Fig. 2 clearly shows that one of the products of the reactions has formula $\mathrm{C}_{12} \mathrm{H}_{18} \mathrm{O}_{5}$, which represents for the compound 6-hydroxyhexyl 5-(hydroxymethyl)furan-2-carboxylate (I). There was a very slightly difference between the calculated mass (265.10464) and the measured mass (265.10462). As can be seen in Table 1, four different solvents, those were n-heptane, TEA, DMSO, hexane-1,6-diol, were used as the reaction environment for promoting the oxidation of HMF. The results showed that monoester products had been formed when the reactions were carried out in DMSO and TEA solvents (entry 1 and 6)

ESI-MS analysis was not allowed to detect 6hydroxyhexyl 5-(hydroxymethyl)furan-2-carboxylate (I) quantitatively (only qualitatively). It was not possible to calculate product yield. ESI-MS spectrum in the case of entry 1 and 6 showed that HMF was almost converted completely, while in the other cases (entry 2-5), HMF was almost not converted. 
Table 1. Condition survey for HMF conversion to ester with diol

\begin{tabular}{|c|l|l|l|l|c|c|c|}
\hline Entry & Diol & Catalyst & Base & Solvent & $\begin{array}{c}\text { Temp } \\
\left({ }^{\circ} \mathrm{C}\right)\end{array}$ & Time & Product \\
\hline 1 & hexane-1,6-diol & $\mathrm{Ru} / \mathrm{C}-\mathrm{Co}_{3} \mathrm{O}_{4} @ \mathrm{~N} / \mathrm{C}$ & $\mathrm{K}_{3} \mathrm{PO}_{4}$ & DMSO & 120 & $48 \mathrm{~h}$ & I \\
\hline 2 & hexane-1,6-diol & $\mathrm{Ru} / \mathrm{C}-\mathrm{Co}_{3} \mathrm{O}_{4} @ \mathrm{~N} / \mathrm{C}$ & $\mathrm{K}_{2} \mathrm{CO}_{3}$ & $\mathrm{DMSO}$ & 120 & $48 \mathrm{~h}$ & None \\
\hline 3 & hexane-1,6-diol & $\mathrm{Ru} / \mathrm{C}-\mathrm{Co}_{3} \mathrm{O}_{4} @ \mathrm{~N} / \mathrm{C}$ & $\mathrm{K}_{3} \mathrm{PO}_{4}$ & n-heptane & 120 & $48 \mathrm{~h}$ & None \\
\hline 4 & hexane-1,6-diol & $\mathrm{Ru} / \mathrm{C}-\mathrm{Co}_{3} \mathrm{O}_{4} @ \mathrm{~N} / \mathrm{C}$ & $\mathrm{TEA}$ & $\mathrm{TEA}$ & 80 & $48 \mathrm{~h}$ & None \\
\hline 5 & hexane-1,6-diol & $\mathrm{Ru} / \mathrm{C}-\mathrm{Co}_{3} \mathrm{O}_{4} @ \mathrm{~N} / \mathrm{C}$ & $\mathrm{K}_{2} \mathrm{CO}_{3}$ & TEA & 80 & $48 \mathrm{~h}$ & None \\
\hline 6 & hexane-1,6-diol & $\mathrm{Ru} / \mathrm{C}-\mathrm{Co}_{3} \mathrm{O}_{4} @ \mathrm{~N} / \mathrm{C}$ & $\mathrm{K}_{3} \mathrm{PO}_{4}$ & TEA & 80 & $48 \mathrm{~h}$ & I \\
\hline 7 & hexane-1,6-diol & $\mathrm{Ru} / \mathrm{C}-\mathrm{Co}_{3} \mathrm{O}_{4} @ \mathrm{~N} / \mathrm{C}$ & $\mathrm{K}_{3} \mathrm{PO}_{4}$ & Hexane-1,6-diol & 120 & $48 \mathrm{~h}$ & None \\
\hline 8 & butane-1,4-diol & $\mathrm{Ru} / \mathrm{C}-\mathrm{Co}_{3} \mathrm{O}_{4} @ \mathrm{~N} / \mathrm{C}$ & $\mathrm{K}_{3} \mathrm{PO}_{4}$ & DMSO & 120 & $48 \mathrm{~h}$ & None \\
\hline
\end{tabular}

*All of these reactions included 2 steps as described in the experimental section, and oxygen 1 bar was used as an oxidant

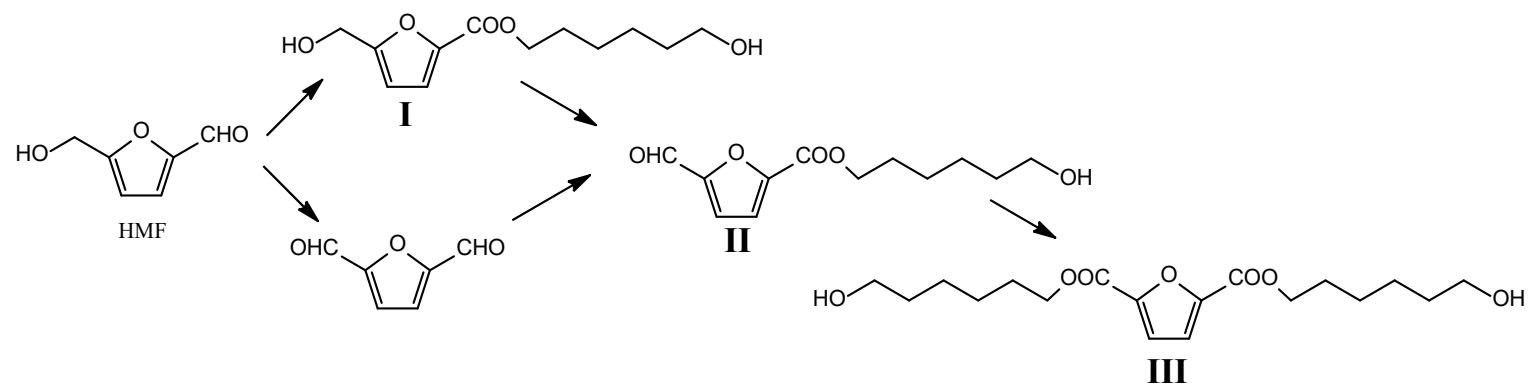

Fig. 1. Possible pathways and products for the oxidative esterification of HMF with hexane-1,6-diol

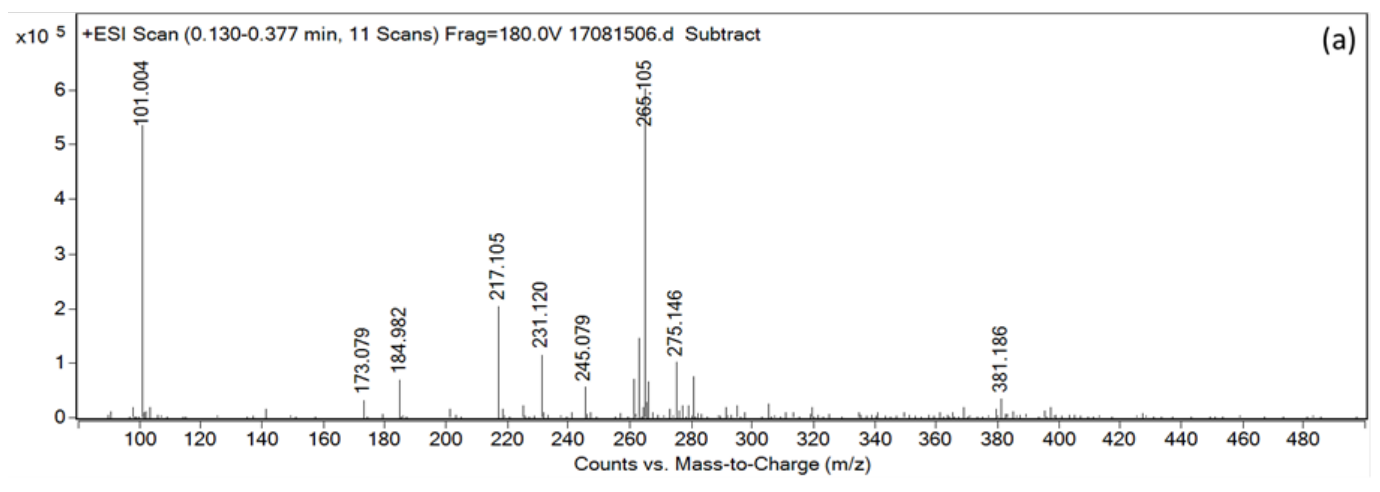

(b)

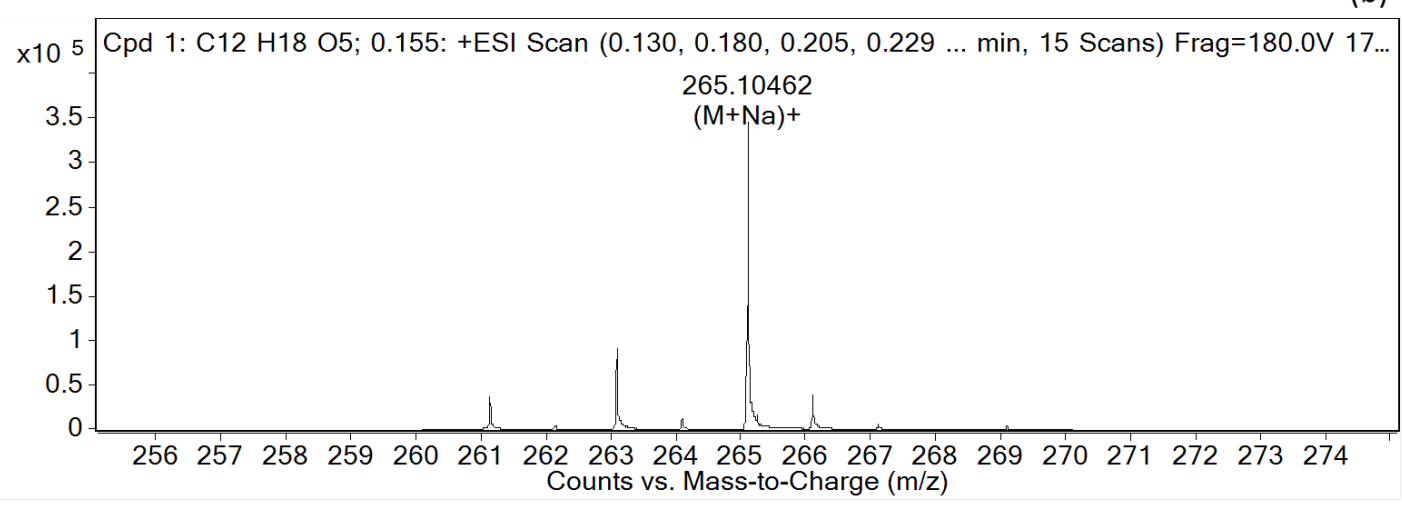

Fig. 2. ESI-TOF mass spectrum of the crude product obtained from a reaction between HMF and hexane-1,6-diol (a) Full spectrum (b) Zoomed spectrum of the possible desired product (Entry 1). 
Dimethyl sulfoxide (DMSO) is an important polar aprotic solvent that dissolves both polar and nonpolar compounds and is miscible in a wide range of organic solvents as well as water. The conversion of aldehydes to esters proceeds best if the reaction is performed in the alcoholic organic solvent in order to circumvent the formation of carboxylic acids. In addition, due to the poor mobility caused by intermolecular hydrogen bonds, as well as the long carbon chain in diol molecules that the use of alcohol as a reaction solvent was unfavorable for the transformation of HMF (entry 7). The studies are underway with mixed solvents and show promising indications that the oxidation to carboxylic acids could be retarded in favor of esterification. Thus, it could be possible to lessen the amounts of alcohol used in the oxidation [27].

Similar to the oxidation of aldehyde to acid in water in the present of heterogeneous catalysis, which forms an intermediate gem diol, a hemiacetal is formed in the oxidation reaction to the ester $[15,18,19]$. The formation of hemiacetal is a nucleophilic reaction, in which the formation of intermediate anions occurs in the presence of bases. Several polarizing solvents such as TEA and DMSO, especially the high anionsolvation ability of DMSO play an important role in promoting the formation of intermediates and stabilizing these products.

\subsection{Alkanediol Screening}

The presence of a second hydroxyl group in molecules of which negative inductive effect reduces the role of diol to act as a nucleophile during the formation of hemiacetal. This effect strongly depends on alkyl chain length. In particular, this effect will decrease along with the increase of alkyl chain length. However, a long carbon-chain reduces the mobility of alcohol in the reaction solution, while also block the diffusion of diols into the active sites inside the catalytic capillary, and thus reduce catalytic activity.

According to the results showed in Table 1, the deactivation of the diol-second hydroxyl group was the most decisive factor that determines the conversion of reactants to ester. Indeed, although butane-1,4-diol and hexane-1,6-diol were both utilized for esterification with HMF (in entry 8 and entry 1-7 respectively), however, ester product only appeared in entry 1 and entry 6, in which hexane-1,6-diol was used. Even so, a longer carbon-chain alcohol may require a slightly higher reaction temperature for an effective esterification process [13].

\subsection{Effect of Base}

In this study, three different bases with increasing basicity are $\mathrm{K}_{2} \mathrm{CO}_{3}$, TEA and $\mathrm{K}_{3} \mathrm{PO}_{4}$ were used in the esterification of HMF with long-chain alkanediols. Among these bases, ester products only formed in the reactions that used $\mathrm{K}_{3} \mathrm{PO}_{4}$. Thus, the results show that the influence of different basicity is consistent with the conclusions about the role of the hemiacetal formation stage, where the base acts as a catalyst for this nucleophilic stage.

However, the difference in basicity of these bases is not too much, therefore this influence may not make a huge different in the esterification of HMF. Due to the low esterification efficiency, further studies still need to be done before a conclusion on the influence of $\mathrm{K}_{3} \mathrm{PO}_{4}$ on product selectivity could be made.

\section{Conclusion}

By setting up a series of reaction with various conditions and using LC/MS/MS analysis to investigate the suitable conditions for the oxidative esterification of HMF with diols, the optimal reaction conditions were found. The chosen conditions for the formation of 6-hydroxyhexyl 5-(hydroxymethyl) furan-2-carboxylate were: $\mathrm{Co}_{3} \mathrm{O}_{4}-\mathrm{N} / \mathrm{C}$ and $\mathrm{Ru} / \mathrm{C}$ catalysts, solvent DMSO or TEA, base $\mathrm{K}_{3} \mathrm{PO}_{4}$, and oxygen 1 bar as an oxidant.

Although our work did not provide a certain evidence for the structure of the formed product, it still indicated the capability to convert $\mathrm{HMF}$ to potential esters using $\mathrm{Co}_{3} \mathrm{O}_{4}-\mathrm{N} / \mathrm{C}$ and $\mathrm{Ru} / \mathrm{C}$ as a catalyst system. Besides, isolation of the desired product to confirm its structure, determining and controlling the efficiency of the esterification are still remaining problems. These problems will be kept on researching, as they will contribute to construct a sustainable science and technology platform for the future.

\section{Acknowledgments}

This research is funded by Vietnam National Foundation for Science and Technology Development (NAFOSTED) under grant number 104.02-2019.12.

\section{References}

[1] C. Voirin, S. Caillol, N.V. Sadavarte, B.V. Tawade, B. Boutevin, P.P. Wadgaonkar, Functionalization of cardanol: towards biobased polymers and additives, Polymer Chemistry, 5 (2014) 3142-3162. https://doi.org/10.1039/C3PY01194A

[2] D. Zhang, M.J. Dumont, Advances in polymer precursors and bio-based polymers synthesized from 5-hydroxymethylfurfural, Journal of Polymer Science Part A: Polymer Chemistry, 55 (2017) 1478-1492. https://doi.org/10.1002/pola.28527

[3] M. Fache, E. Darroman, V. Besse, R. Auvergne, S. Caillol, B. Boutevin, Vanillin, A promising biobased building-block for monomer synthesis, Green Chemistry, 16 (2014) 1987-1998. https://doi.org/10.1039/C3GC42613K

[4] L.M. de Espinosa, M.A. Meier, Plant oils: The perfect renewable resource for polymer science, European Polymer Journal, 47 (2011) 837-852.

[5] A.A. Rosatella, S.P. Simeonov, R.F. Frade, C.A. Afonso, 5-Hydroxymethylfurfural (HMF) as a 
building block platform: Biological properties, synthesis and synthetic applications, Green Chemistry, 13 (2011) 754-793.

https://doi.org/10.1016/j.eurpolymj.2010.11.020

[6] Y. Su, H.M. Brown, X. Huang, X.-d. Zhou, J.E. Amonette, Z.C. Zhang, Single-step conversion of cellulose to 5-hydroxymethylfurfural (HMF), a versatile platform chemical, Applied Catalysis A: General, 361 (2009) 117-122.

https://doi.org/10.1039/c0gc00401d

[7] Y. Mao, R.M. Kriegel, D.G. Bucknall, The crystal structure of poly (ethylene furanoate), Polymer, 102 (2016) 308-314. https://doi.org/10.1016/j.polymer.2016.08.052

[8] A. Codou, M. Moncel, J.G. van Berkel, N. Guigo, N. Sbirrazzuoli, Glass transition dynamics and cooperativity length of poly (ethylene 2, 5furandicarboxylate) compared to poly (ethylene terephthalate), Physical Chemistry Chemical Physics, 18 (2016) 16647-16658. https://doi.org/10.1039/C6CP01227B

[9] V. Tsanaktsis, D.G. Papageorgiou, S. Exarhopoulos, D.N. Bikiaris, G.Z., Papageorgiou, crystallization and polymorphism of poly (ethylene furanoate), Crystal Growth \& Design, 15 (2015) 5505-5512.

https://doi.org/10.1021/acs.cgd.5b01136

[10] G.Z. Papageorgiou, V. Tsanaktsis, D.N. Bikiaris, Synthesis of poly (ethylene furandicarboxylate) polyester using monomers derived from renewable resources: thermal behavior comparison with PET and PEN, Physical Chemistry Chemical Physics, 16 (2014) 7946-7958

https://doi.org/10.1039/C4CP00518J

[11] S.K. Burgess, O. Karvan, J. Johnson, R.M. Kriegel, W.J. Koros, Oxygen sorption and transport in amorphous poly (ethylene furanoate), Polymer, 55 (2014) 4748-4756.

https://doi.org/10.1016/j.polymer.2014.07.041

[12] R.V. Jagadeesh, T. Stemmler, A.-E. Surkus, M. Bauer, M.-M. Pohl, J. Radnik, K. Junge, H. Junge, A. Brückner, M. Beller, Cobalt-based nanocatalysts for green oxidation and hydrogenation processes, Nature protocols, 10 (2015) 916 .

https://doi.org/10.1038/nprot.2015.049
[13] R.V. Jagadeesh, H. Junge, M.-M. Pohl, J.r. Radnik, A. Brückner, M. Beller, Selective oxidation of alcohols to esters using heterogeneous $\mathrm{Co}_{3} \mathrm{O}_{4}-\mathrm{N} @ \mathrm{C}$ catalysts under mild conditions, Journal of the American Chemical Society, 135 (2013) 10776-10782. https://doi.org/10.1021/ja403615c

[14] J. Deng, H.J. Song, M.S. Cui, Y.P. Du, Y. Fu, Aerobic oxidation of hydroxymethylfurfural and furfural by using heterogeneous $\mathrm{Co}_{\mathrm{x}} \mathrm{O}_{\mathrm{y}}-\mathrm{N} @ \quad \mathrm{C}$ catalysts, ChemSusChem, 7 (2014) 3334-3340. https://doi.org/10.1002/cssc.201402843

[15] A. Salazar, P. Hünemörder, J. Rabeah, A. Quade, R.V. Jagadeesh, E.J.A.S.C. Mejia, Engineering, synergetic bimetallic oxidative esterification of 5hydroxymethylfurfural under mild conditions, 7 (2019) 12061-12068. https://doi.org/10.1021/acssuschemeng.9b00914

[16] M. Jiang, Q. Liu, Q. Zhang, C. Ye, G. Zhou, A series of furan-aromatic polyesters synthesized via direct esterification method based on renewable resources, Journal of Polymer Science Part A: Polymer Chemistry, 50 (2012) 1026-1036. https://doi.org/10.1002/pola.25859

[17] J. Zhu, J. Cai, W. Xie, P.-H. Chen, M. Gazzano, M. Scandola, R.A. Gross, Poly (butylene 2, 5-furan dicarboxylate), a biobased alternative to PBT: synthesis, physical properties, and crystal structure, Macromolecules, 46 (2013) 796-804. https://doi.org/10.1021/ma3023298

[18] G. An, H. Ahn, K.A. De Castro, H. Rhee, Pd/C and $\mathrm{NaBH} 4$ in basic aqueous alcohol: an efficient system for an environmentally benign oxidation of alcohols, Synthesis, 2010 (3) 477-485. https://doi.org/10.1055/s-0029-1217115

[19] S.E. Davis, M.S. Ide, R.J. Davis, Selective oxidation of alcohols and aldehydes over supported metal nanoparticles, Green Chemistry, 15 (2013) 17-45. https://doi.org/10.1039/C2GC36441G 